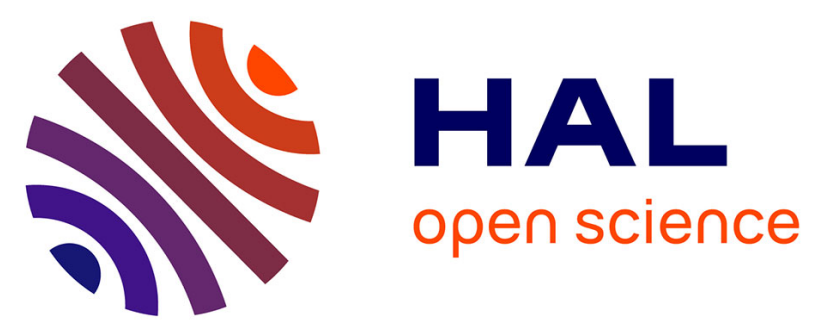

\title{
New perspectives on Late Bronze Age lagoon sites in the South of France revealed by animal exploitation at the La Motte I site (Hérault)
}

\author{
Carole Lespes, Thibault Lachenal, Armelle Gardeisen, Jean Gascó
}

\section{- To cite this version:}

Carole Lespes, Thibault Lachenal, Armelle Gardeisen, Jean Gascó. New perspectives on Late Bronze Age lagoon sites in the South of France revealed by animal exploitation at the La Motte I site (Hérault). Journal of Archaeological Science: Reports, 2019, 25, pp.206-216. 10.1016/j.jasrep.2019.04.005 . halshs-02428696

\author{
HAL Id: halshs-02428696 \\ https://shs.hal.science/halshs-02428696
}

Submitted on 22 Oct 2021

HAL is a multi-disciplinary open access archive for the deposit and dissemination of scientific research documents, whether they are published or not. The documents may come from teaching and research institutions in France or abroad, or from public or private research centers.
L'archive ouverte pluridisciplinaire HAL, est destinée au dépôt et à la diffusion de documents scientifiques de niveau recherche, publiés ou non, émanant des établissements d'enseignement et de recherche français ou étrangers, des laboratoires publics ou privés.

\section{(ㄷ)(1) $\$$}

Distributed under a Creative Commons Attribution - NonCommerciall 4.0 International 
Version of Record: https://www.sciencedirect.com/science/article/pii/S2352409X18304851

Manuscript_35e7ee79b74bc06846fda8ed78196fe1

1 Title

2 New perspectives on Late Bronze Age lagoon sites in the South of France revealed by animal

3 exploitation at the La Motte I site (Hérault)

\section{Author}

5 Carole LESPES asm - archéologie des sociétés méditerranéennes, umr 5140, univ paul-valéry, cnrs, f-34000, Montpellier. labex

7 Thibault LACHENAL asm - archéologie des sociétés méditerranéennes, umr 5140, univ paul-valéry, cnrs, f-34000, Montpellier. labex

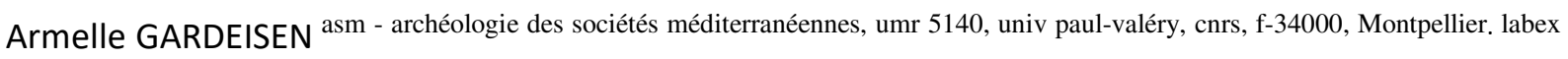

Jean GASCÓ asm - archéologie des sociétés méditerranéennes, umr 5140, univ paul-valéry, cnrs, f-34000, Montpellier. labex archimede

\section{Corresponding author: Carole Lespes}

E-mail: carolelespes1@gmail.com

Postal address: Université Paul Valéry - Site Saint-Charles

\section{FRANCE}


At the present time, only a few Late Bronze Age sites in the French Mediterranean have yielded faunal data. The newly excavated site of La Motte I (Hérault, France) is exceptionally well preserved owing to its underwater context. The discovery of large quantities of pottery, a wattle and some wooden poles allowed the site to be dated to the Late Bronze Age IIlb (900-775 BC). The zooarchaeological analysis of the mammalian remains has made it possible to identify the nature of butchery operations at the site. Culling profiles show herd management practices during this period and bring to light specific dietary practices. These data reveal meat procurement behaviour in this Bronze Age Mediterranean population, highlighting regular meat acquisition from domestic livestock.

Highlights:

- Zooarchaeological analysis of an exceptionally well-preserved Late Bronze Age lagoon occupation in Mediterranean southern France.

- Food production is strongly oriented towards land-based resources despite the proximity of the lagoon and the sea.

- Meat consumption of this Late Bronze Age Mediterranean population was mainly composed of young domestic animals.

Keywords: Late Bronze Age; French Mediterranean; culling profile; herd management; lagoons

1. Introduction

The Bronze Age and the beginning of the Iron Age in France are the subject of a recent overview (Carozza et al., 2017). This evaluation of French data for the Late Bronze Age indicates a hierarchical organisation, linked to elite status. There is clear evidence for the expansion of fortified settlements, located at strategic locations such as confluence points or on rocky outcrops. While housing data and archaeological evidence (ceramics, metal tools, structures) are available, zooarchaeological analyses 
are still comparatively rare. Indeed, faunal data in Languedoc at the end of the Bronze Age (Final Bronze IIIb) are extremely scant. Most of the zooarchaeological studies for Languedoc deal with earlier periods or different contexts, such as Castelvielh Cave for the Final Bronze Illa (Gardeisen, 1991) or Les Courtinals settlement for the Final Bronze II and IIla (Poulain, 2002). For the Final Bronze IIIb, they mainly consist of simple faunal lists accompanied by basic interpretation (Columeau, 1985; 2002). However, rescue archaeology has sparked new interest in this period among researchers for the Mediterranean region of France. Moreover, the French Mediterranean context differs slightly from Late Bronze Age continental sites, both in terms of chronology (Table 1) and culture, as it is influenced by the proximity of Iberia and Italy, and presents specific local characteristics (Garcia and Vital, 2006; Gascó, 1998; Lachenal, 2014; Py, 2012).

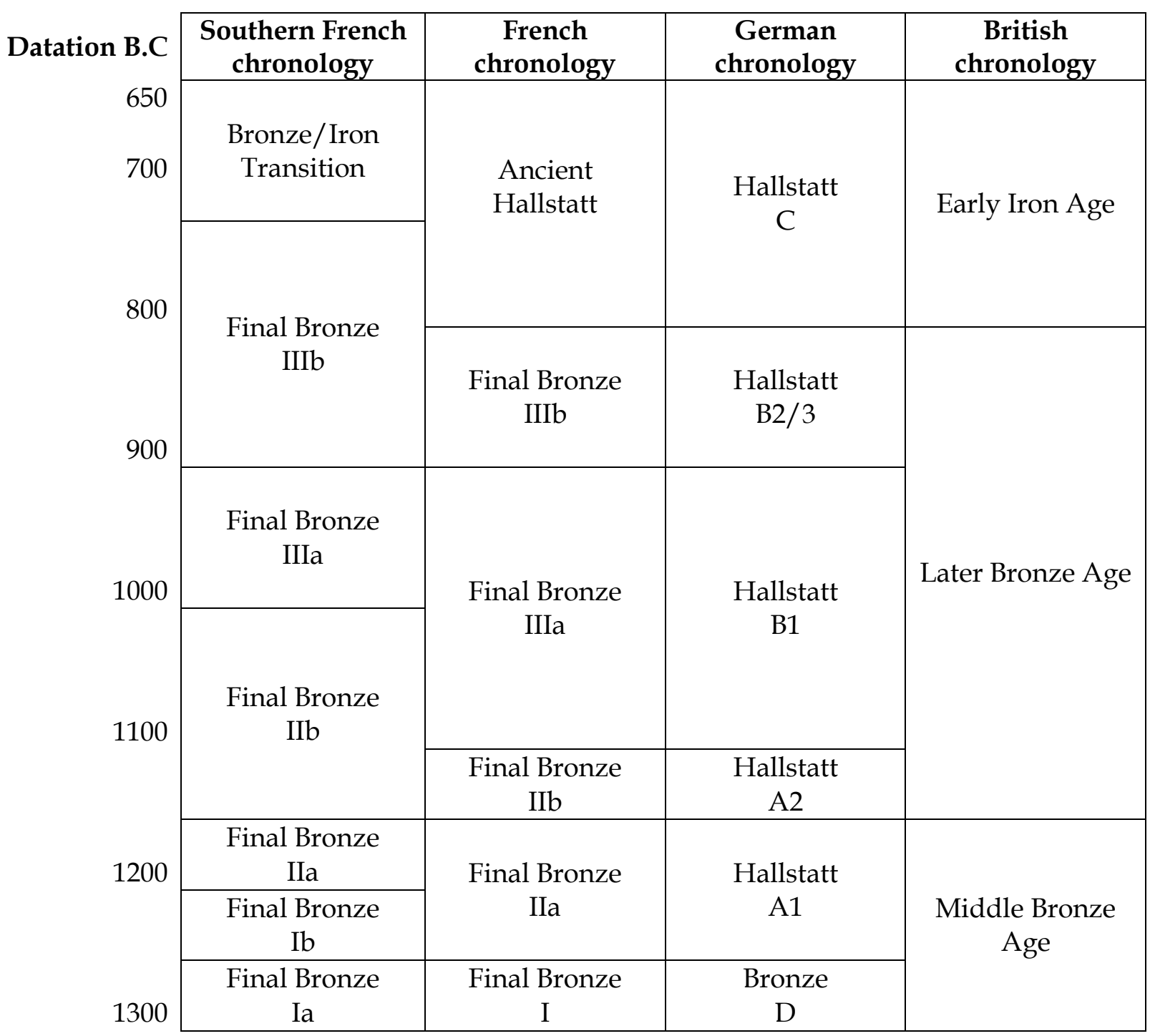




\begin{tabular}{|c|c|c|c|}
\hline & & \\
& & & \\
& & & \\
& Middle Bronze & Middle Bronze & Bronze \\
2 & 2 & C2 & \\
\hline
\end{tabular}

Tab. 1: Comparative chronology of the Late Bronze Age and beginnings of the Iron Age in Europe.

The present zooarchaeological analysis provides new perspectives on the way of life of these

Mediterranean populations. Geomorphological studies show that the housing site of La Motte I was

located on the edge of a former lagoon (Devillers et al., forthcoming), suggesting that it was mainly organized around maritime resources. However, this study shows that terrestrial resources appear to supply important staple foods for these inhabitants. It is clear that such specific types of sites must be compared to previously studied sites (Columeau, 1985) in Languedoc and in the North of France, such as Boulancourt (Seine-et-Marne) and sites in Aisne (Auxiette, 1997; Bălăşescu et al., 2008;

Carozza et al., 2017). These sites date from the Late Bronze Age and should reveal whether there are similarities in meat consumption between southern and northern France.

Lagoon complexes in the Gulf of Lion (Fig. 1) offered an attractive area for Bronze Age populations. Indeed, lagoons are convenient locations, with a variety of readily available food resources and nearby cultivable land. The first excavations of such sites began in 1940 at the Bages-Sigean lagoon (Guy, 1950). Interest in them was subsequently revived after the discovery of protohistoric settlements in the Lez Delta, such as Port Ariane in Lattes, Hérault (Daveau, 2007). Local archaeologists discovered several sites (Fig. 1) on the edge of the Or Lagoon (Arnal and Prades, 1980; Dedet et al., 1985; Prades, 1974), in the Thau Lagoon (Courtin, 1978; Leroy et al., 2003) and in Vendres (Carozza and Burens, 2000). The Or Lagoon sites were first considered to be transient sites, on herd transhumance routes (Py, 1990). In other words, it was thought that local populations lived near the coast in summer with their herds and moved with them during the wet season to highaltitude sites in mountainous areas. But this hypothesis has since been challenged by recent 
paleobotanical studies (Bouby, 2014) and the Portal-Vielh excavations (Carozza and Burens, 2000), which show that these lagoon habitats were used year-round.

2. Site presentation

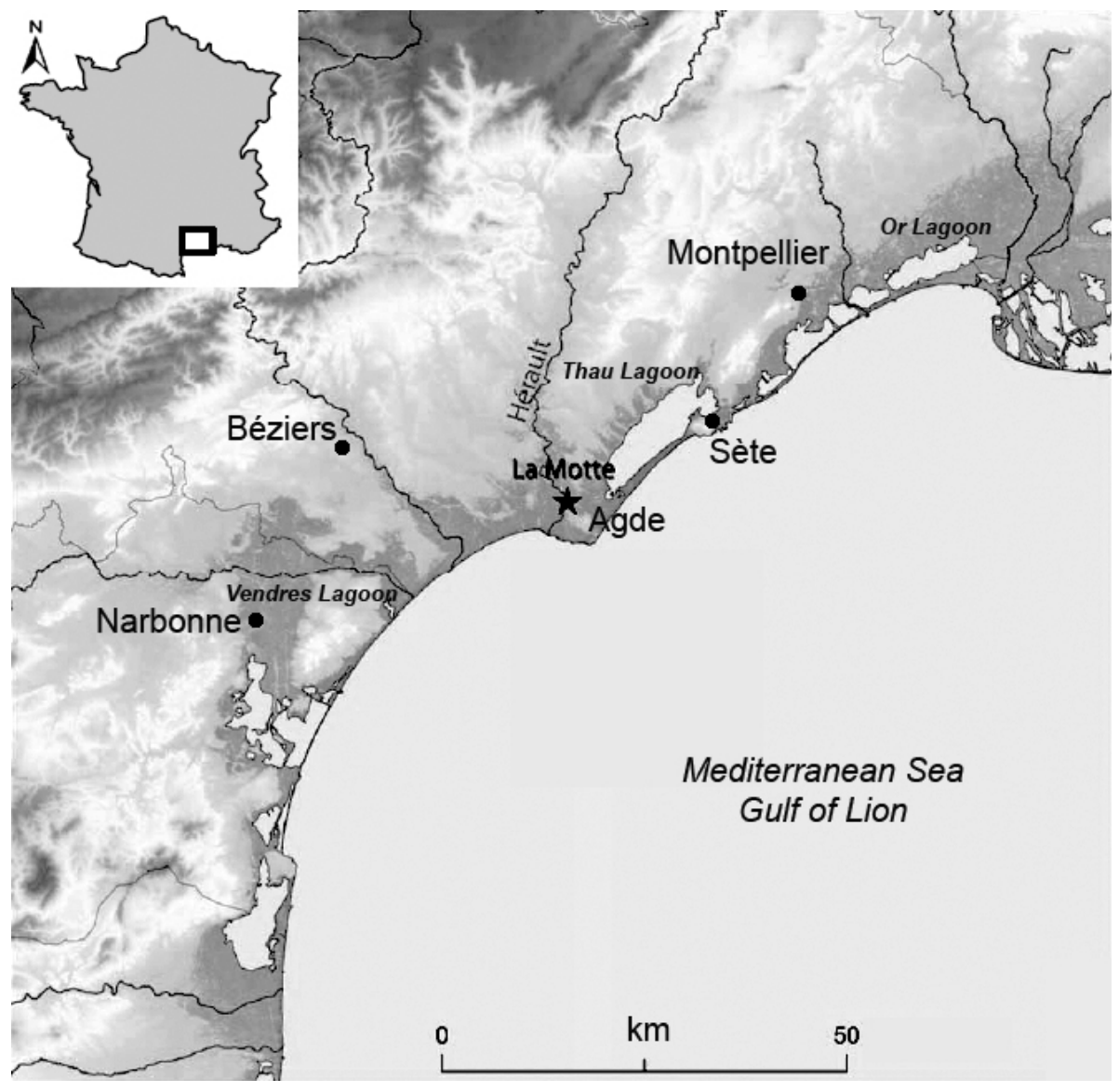

Fig. 1: Geographical location of the archaeological site of La Motte I (CAD, T.Lachenal), modified.

La Motte I is situated in the South of France near the town of Agde (Fig.1). The underwater site is currently submerged in the Hérault River and was discovered by the IBIS diving association in 2002. During the first excavations in 2004, a hoard consisting of an almost complete set of feminine finery was discovered (Moyat et al., 2010; Verger et al., 2007). Surveys were then conducted by J. Gascó and T. Lachenal in 2011 and are still ongoing (Gascó et al., 2015). A planimetric survey and excavations were carried out by divers at two different sites on either side of the river bed and cover $3,000 \mathrm{~m}^{2}$ (Fig. 2). 


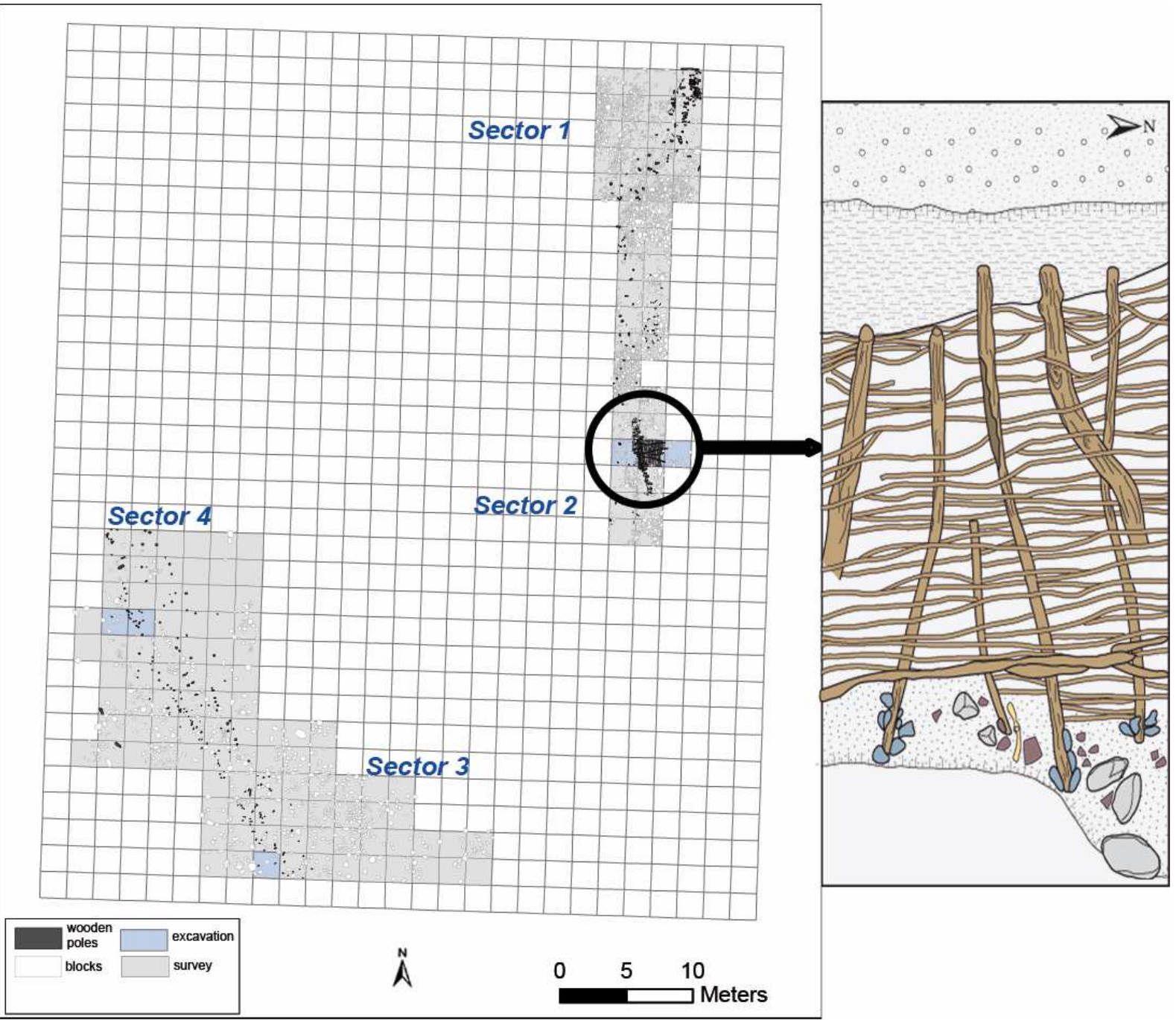

Fig 2 (in colour): Map of the excavation of La Motte I in the Hérault River with detailed view of the wattle (CAD, T. Lachenal), modified.

This housing site was originally located on the edge of a former lagoon (Devillers et al., forthcoming), which has since been filled with sediments from the Hérault. The remains are immersed under five metres of water and, as a result, are exceptionally well preserved. The large quantity of organic remains in the sediments allows for a precise reconstruction of the evolution of the paleoenvironment and human activities. Ten wooden poles were radiocarbon dated and gave dates ranging from the ninth to eighth centuries B.C. (Gascó et al., 2015). These dates are consistent with the analysis of pottery (Lachenal et al., 2017) corresponding to the Late Bronze Age (ninth to early eighth centuries) and linked to the establishment of the Mailhac I culture in Languedoc (Gailledrat et al., 2007; Janin, 2000; Louis et al., 1955). The site also presents riverbank structures, comprising imported basalt rocks and wattle, demonstrating the reinforcement of the banks and the 
delimitation of an inhabited zone. The hypothesis of a semi-nomadic way of life for these lagoon populations (Py, 1990) has been challenged by recent discoveries. Therefore, the question of permanent settlement at La Motte I remains open. Nevertheless, the excavated levels in which the faunal remains were discovered are primarily waste deposits in the vicinity of the dwelling area and are close to the riverbank structures. In addition, the carpological analysis (Bouby et al., 2016) revealed that the population living at the site was actively involved in agricultural production and practised herd stalling. These factors suggest perennial settlement for the La Motte I site. The analysis of the faunal remains from La Motte I should therefore be expected to confirm these initial results.

\section{Materials and methods}

Faunal bones and teeth were collected from all excavation areas in different stratigraphic units and in $2 \mathrm{~m} \times 2 \mathrm{~m}$ squares (Sector 1, 2, 3 and 4; Fig. 2). Three samples were collected for the carpological study in the D26 sounding (SU 4, 15 and 18) and in the wattle zone. These samples were sieved but no faunal remains were found. As the entire sequence of stratigraphic units was dated to the end of the Bronze Age, all the faunal remains were analysed (Table A in the appendices) and recorded by stratigraphic unit and square in the Syslat@ database.

The complete collection consists of 1,321 mammal, bird, shellfish and fish remains. The shellfish and fish remains are not analysed in this study as they will be studied in detail by other specialists. The taxonomic and anatomical determination was carried out using the reference faunal sampling at the ASM laboratory of the University of Montpellier 3 (CNRS, UMR 5140).

The differential diagnosis between Capra hircus and Ovis aries teeth (Balasse and Ambrose, 2005; Halstead et al., 2002; Helmer, 2000; Payne, 1985) has been contested (Zeder and Pillar, 2010) but a recent study (Gillis et al., 2011) highlighted the reliability of the combination of several criteria. As the bones are well preserved at La Motte I, most mandibular and maxillary bones contain whole dental series, which facilitated differentiation between sheep and goats. With the post-cranial data, 
a primary distinction was made based on morphological criteria (Boessneck, 1969, Zeder and Lapham, 2010) and confirmed by discriminant analysis (Salvagno and Albarella, 2017). The distinction between rabbits (Oryctolagus cuniculus) and hares (Lepus europaeus) was made using specific morphological criteria (Callou, 1997).

The quantification of faunal remains is expressed by the Number of Identified Specimens (NISP), which includes taxonomically and anatomically identified bones and teeth, and the Minimum Number of Individuals combination (MNIc). The NMIc takes into account species, element frequency, pairing, ageing and sex. The complete dental series on the mandible and maxillary and isolated teeth were used to calculate the MNIc index, taking into account eruption sequence and wear. The age at death (AtD) was defined for large bovids using the most accurate method (Legge, 1992; Gillis et al., 2016), in order to be as precise as possible. The use-wear code method was applied to Caprinae (Payne, 1987). To estimate the AtD value of suids, we used a method based on ranking codes (Grant, 1982; Lemoine et al., 2014).

Culling profiles were calculated in accordance with the recommendations of Brochier, who elaborated a statistically correct method that allows for accurate interpretation (Brochier, 2013). Insofar as possible, age analysis was based on bone epiphyseal fusion (Zeder et al., 2015 for Suidae, Reitz and Wing, 1999).

Standard biometrics (Von den Driesch, 1976) were performed on all bones and teeth whenever possible in order to distinguish between Ovis aries and Capra hircus, Bos Taurus and Bos primigenius, and to estimate the withers height of the animals. The body size of animals was investigated using reference coefficients for Caprinae (Teichert, 1975), Bovidae (Matolcsi, 1970) and Equidae (Kiesewalter, 1888), to provide a view of the domestic herd present in this region at the end of the Bronze Age.

Skeletal representation is divided into four categories: cranial remains include the skull, mandible and jaw, the axial skeleton is composed of vertebrae and ribs, the limbs include the forelimbs 
154 (scapula, humerus, radius and ulna) and hindlimbs (coxal, femur, tibia and fibula) and finally the feet 155 include carpals, tarsals, metapodials and phalanxes. The following indices were used in this study in 156 order to determine whether anatomical parts were differentially deposited (Lyman, 2008; Poplin 157 1976):

158

159

MNE: Minimum Number of Elements (i.e. a humerus) tallied after virtual reassembly taking into account pairing, ageing and the sex of all bone remains for a species.

Qsp: This is the number of given elements in a complete skeleton for a species. It can vary according to age (i.e. number of teeth) and species.

MAU: Minimum Animal Unit. This is the frequency of skeletal MNE for a given species.

\section{$\mathrm{MAU}=\mathrm{MNE} / \mathrm{Qsp}$}

\%MAU: This is the normalized MAU calculated from the highest MAU corresponding to $100 \%$.

$\% \mathrm{MAU}=100 \times \mathrm{MAU} / \mathrm{MAU}_{\max }$

PS: The percentage of survivorship is calculated for each element and can be applied to the anatomical region (cranial, axial, limb and foot) and to the entire skeleton using the MAU and MNIc.

$\mathrm{PS}=100 \times \mathrm{MNE} / \mathrm{MNIcxQsp}$

Bone surface modifications were studied in order to identify their causes and to characterize their impact on bone assembly. The cortical surface of all remains was analysed macroscopically and some specimens were inspected microscopically with a Leica stereomicroscope. The orientation and location of marks on the bone were recorded. The marks were then separated into five categories (Fig. 3): notches associated with large tools forming a large triangular depression; slicing, generally made with a cleaver, exposing a sharp section of the bone; scratches, created by knives and forming fine notches on the cortical surface; cortical removal, made either by cleavers or knives and 


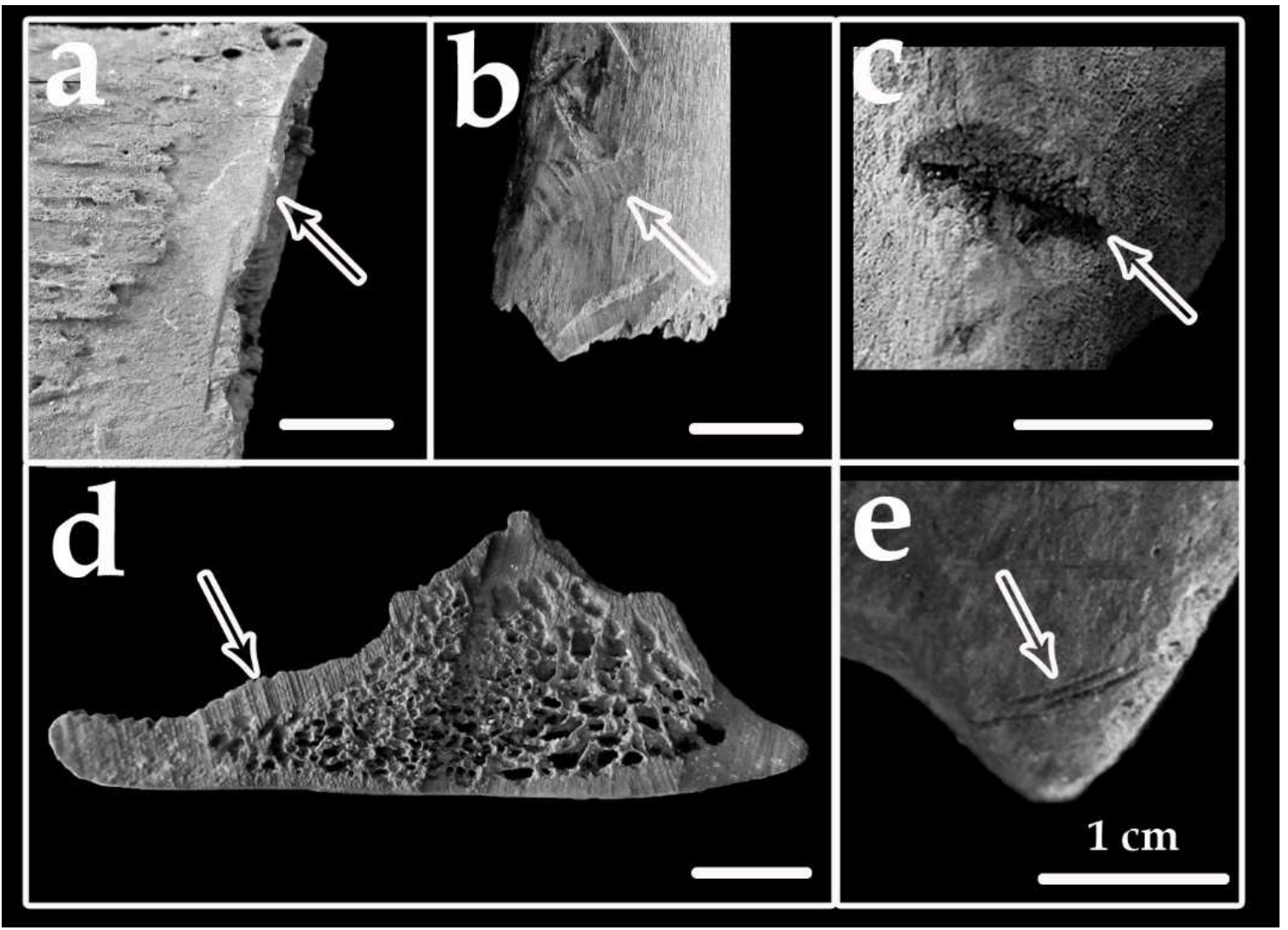

Fig. 3: Anthropogenic modifications to bone surface. a: slicing (cutting); b: cortical removal b; c: notches; d: sawing; e: scratches.

Non-anthropogenic post-depositional marks were also investigated and classified into the following categories: root marks, gnawing by carnivores and rodents, and edaphic marks.

All faunal remains were registered in the SyslatCC database (Py 1997; Gardeisen 1997).

4. Results

\subsection{Taxon diversity}

5 The faunal assemblage of La Motte I is composed of 1,321 remains (total of identified and unidentified faunal remains), including 685 identified bones and teeth (NISP). They belong to fourteen species: cattle (Bos taurus), sheep (Ovis aries), goats (Capra hircus), pigs or wild boars 

Annexes Table A).

\begin{tabular}{|c|c|c|c|}
\hline \multicolumn{2}{|c|}{ FAUNAL LIST } & \multirow{2}{*}{$\begin{array}{c}\text { NISP } \\
215\end{array}$} & \multirow{2}{*}{$\frac{\text { MNIc }}{49}$} \\
\hline Cattle & Bos taurus & & \\
\hline Aurochs & Bos primigenius & 3 & 1 \\
\hline Suid & Sus scrofa & 99 & 40 \\
\hline Sheep & Ovis aries & 26 & 20 \\
\hline Goat & Capra hircus & 44 & 31 \\
\hline Sheep/Goat & Ovis/Capra & 183 & 35 \\
\hline Horse & Equus caballus & 10 & 6 \\
\hline Dog & Canis lupus familiaris & 16 & 10 \\
\hline Deer & Cervus elaphus & 55 & 16 \\
\hline Rabbit & Oryctolagus cuniculus & 24 & 8 \\
\hline Pond terrapin & Emys orbicularis & 2 & 2 \\
\hline \multirow[t]{4}{*}{ Cormorant } & Phalacrocorax sp. & 3 & 2 \\
\hline & Birds indet. & 3 & 3 \\
\hline & Carnivore indet. & 1 & 1 \\
\hline & Microfauna & 1 & 1 \\
\hline \multirow[t]{2}{*}{ Sea bream } & Sparus aurata & $*$ & $*$ \\
\hline & Unidentified & & \\
\hline Total & Total & 1,321 & 225 \\
\hline
\end{tabular}

Tab 2: Quantification of the faunal assemblage recovered from the La Motte I site. Number of Identified Specimens (NISP) and Minimum Number of Individuals combination (MNIc). *Although the ichthyofaunal remains will soon be analysed by a specialist, rare Sparus aurata remains have already been determined.

Among the species present at La Motte I, the domestic triad (Bos taurus, Ovis aries/Capra hircus, Sus scrofa) prevails. Livestock is mainly composed of goats and sheep, which is common in 


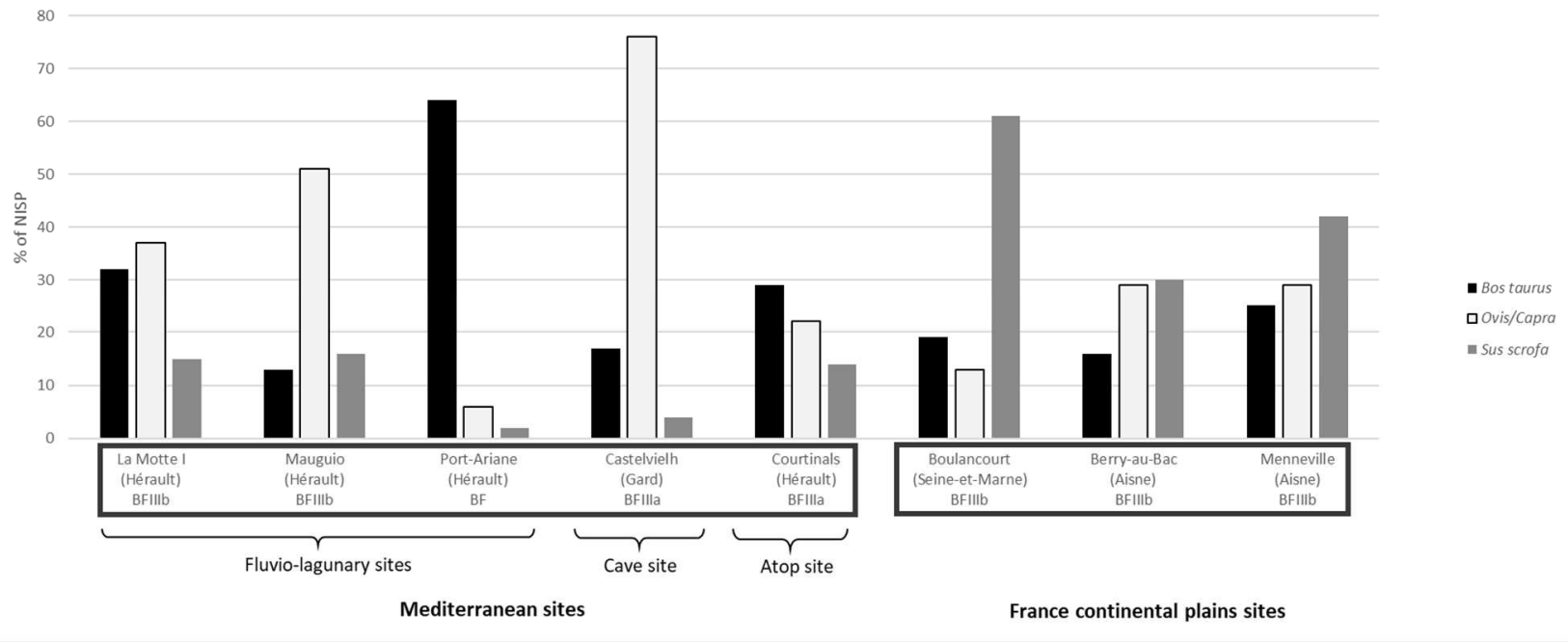

Fig. 4: Comparison of the distribution of the domestic triad in Late Bronze Age sites in France (Columeau, 1985; Forest, 2007; Gardeisen, 1991; Poulain, 2002; Auxiette, 1997).

It is generally accepted that evidence of pig farming generally increased in France at the end of the Bronze Age (Forest, 2000; Auxiette, 1997), with Sus scrofa forming more than $20 \%$ of the NISP, which is not the case at La Motte. Pig farming developed considerably (more than $30 \%$ of the NISP) in many French continental plains (Fig. 4), but not in Mediterranean sites where husbandry practices seemed to focus more on goats or cattle. For example, in the vicinity of the Mauguio pond (Columeau, 1985), caprines predominate, followed by pigs and cattle. In Port-Ariane (Hérault, France), cattle are clearly predominant, which is counter to the classic Mediterranean pattern (Forest, 2007), usually dominated by caprines (mainly sheep and to a lesser degree, goats), then cattle, pigs (about $20 \%$ of the faunal assemblage) and deer (about 10\%).

The domestic herd of La Motte I is dominated by caprines in terms of NISP and MNIC, and more precisely by goats, with suid livestock coming in third position after cattle. The importance of goats rather than sheep seems to be an original feature of this site. Indeed, at other sites, such as Castelvielh (Gard) or Les Courtinals (Hérault), sheep are the best represented taxon. But this slight difference should be interpreted with caution, as these two sites are dated respectively to the Final Bronze IIla and Final Bronze II-IIla and correspond to different types of occupations (cave and hilltop 
settlement). This first approach shows that the faunal remains represent classic Late Bronze Age

Mediterranean animal husbandry. A group of people settled in a developed settlement with a

communal herd sustaining their needs mainly composed of caprines and bovids, followed by suids, with some horses and dogs.

\subsection{Body size}

Only a few complete bones were available for each taxon for this analysis. Withers height was estimated for caprines on one radius, one metacarpal and two astragalii, for Bos taurus (one radius, two metacarpals and two metatarsals) and for Equus caballus (one femur), (Table 3). The results gave a range of $46.1-56.3 \mathrm{~cm}$ for caprines, $103.6-115.6 \mathrm{~cm}$ for cattle, and the single whole horse femur gave a height of $136.7 \mathrm{~cm}$. These results can be compared with those of Boulancourt (Seine-etMarne), Port-Ariane (Hérault) and Castelvielh (Gard). For size estimates at Boulancourt, a single whole metatarsal of Bos taurus gave a height estimate of $108.5 \mathrm{~cm}$; a range of $51.8-63.5 \mathrm{~cm}$ is given for goats and no data are available for horses. In Port-Ariane, the measurements of a bovine metacarpal and an equine metatarsal indicate an estimated size of 117 and $125 \mathrm{~cm}$, respectively. Caprine bones could not be measured. In Castelvielh, the size of the sheep is between 54 and $60 \mathrm{~cm}$. Despite the small number of measurements and estimates, a trend towards a smaller size for goats and cattle is visible while the La Motte I horse seems larger than horses at the other sites (Table 4). But this comparison is unreliable because the distinction between Equus asinus and Equus caballus has not been made at other sites.

\begin{tabular}{c|c|c|c|c}
\multicolumn{1}{c}{ Species } & \multicolumn{1}{c}{ Bones } & GL & \multicolumn{1}{c}{ Index } & Withers height in cm \\
\hline \multirow{4}{*}{ Ovis/Capra } & radius & 139.7 & 4 & 55.9 \\
& metacarpal & 116.3 & 4.84 & 56.3 \\
\cline { 2 - 5 } & \multirow{2}{*}{ astragalus } & 24 & \multirow{2}{*}{19.24} & 46.1 \\
& & 24.6 & & 47.3 \\
\hline \multirow{2}{*}{ Bos taurus } & radius & 237.9 & 4.3 & 102.3 \\
\cline { 2 - 5 } & metacarpal & 173.5 & 6.33 & 109.8 \\
\hline
\end{tabular}




\begin{tabular}{l|c|l|l|l} 
& & 173.5 & & 109.8 \\
& & 163.7 & & 103.6 \\
\cline { 2 - 5 } & \multirow{2}{*}{ metatarsal } & 205.6 & 5.62 & 115.6 \\
& 203.3 & & 114.3 \\
\hline Equus caballus & femur & 389.6 & 3.51 & 136.8
\end{tabular}

Tab. 3: Withers height estimation in $\mathrm{cm}$ for caprines (Ovis/Capra), cattle (Bos taurus) and horses (Equus caballus) at La Motte I.

\begin{tabular}{|c|c|c|c|c|c|}
\hline & $\begin{array}{c}\text { Castelvielh } \\
\text { BFIlla }\end{array}$ & $\begin{array}{l}\text { Port-Ariane } \\
\text { Final Bronze }\end{array}$ & $\begin{array}{c}\text { Boulancourt } \\
\text { BFIIIb }\end{array}$ & $\begin{array}{c}\text { La Motte I } \\
\text { BFIIIb }\end{array}$ & $\begin{array}{l}\text { Cougourlude } \\
\text { Early Iron Age }\end{array}$ \\
\hline Ovis aries/Capra hircus & 57 & $x$ & 58 & 51 & 57 \\
\hline Bos taurus & $x$ & 113 & 109 & 107 & 111 \\
\hline Equus sp. & $x$ & 125 & $x$ & 137 & 107 \\
\hline
\end{tabular}

Tab. 4: Comparison of average withers height for caprines, cattle and equids from the archaeological settlements of Port-Ariane (Hérault),

La Motte I (Hérault), Cougourlude (Hérault), Castelvielh (Gard) and Boulancourt (Seine-et-Marne).

For wild species, three tarsal elements were identified as Bos primigenius on account of their large size. All of the aurochs remains are incomplete, but measurements on a fragmented aurochs astragalus (Bos primigenius) reveal that the La Motte I specimen is probably a huge male, similar to the largest European Pleistocene specimens (Wright, 2013) and larger than Holocene specimens (Helmer and Monchot, 2006; Kysely, 2008; Wright and Viner-Daniels, 2015; Wright, 2013).

Measurements of this aurochs astragalus were compared with other data from Pleistocene and Holocene sites and clearly show the remarkable height of this animal (Fig. 5). This suggests that the environment at that time was conducive to the presence of an aurochs of remarkable size. This is also confirmed by the carpological analysis (Bouby et al., 2016), which shows the presence of a green oak forest and open spaces with heaths and junipers. It also suggests that the size of domestic animals is more related to domestication and selection effects than environmental conditions. 


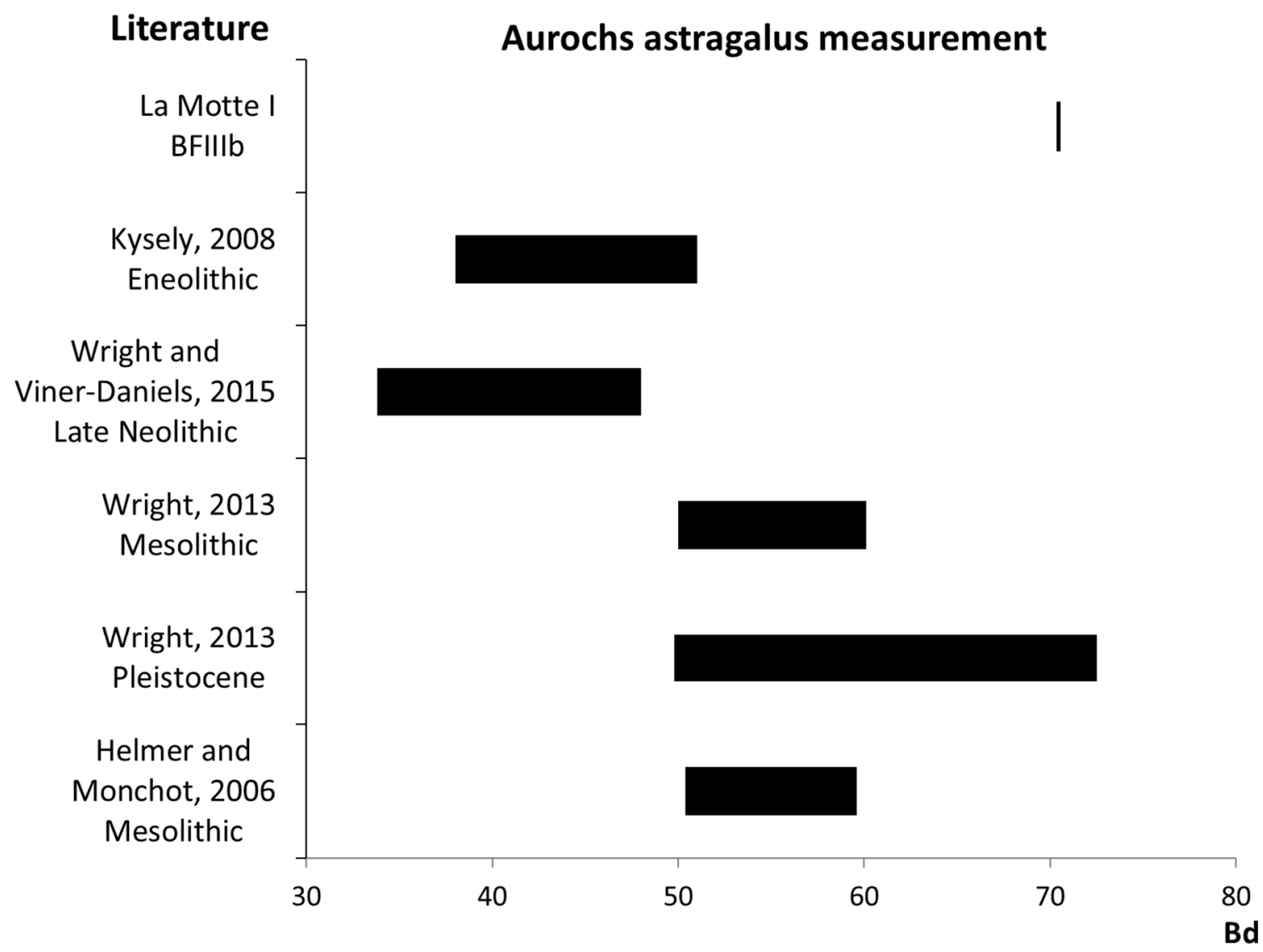

Fig. 5: Comparison of the measurements (Bd) of the aurochs astragalus (Bos primigenius) at La Motte I with other European sites (Wright, 2013; Wright and Viner-Daniels, 2015; Helmer and Monchot, 2006).

\subsection{Skeletal representation}

The anatomical profile of the bone assemblage is characterized by the abundance of cranial and limb remains, followed by axial and foot elements (Fig. 6). The same trend is observed for the triad taxa. As far as possible, ribs and vertebrae were identified to the taxon, but a determination bias (underestimation) should be taken into account for this category. Indeed, when skeletal representation is viewed as a percentage of the total number of faunal remains (anatomically determined but not taxonomically determined), the foot is still rare but the axial category seems better represented. However, this can be explained by the high fragmentation of costal elements. In

271 addition, this under-representation can be explained in part by the high impact of carnivores on

272 bones ( $20 \%$ of the total assemblage shows signs of gnawing). 


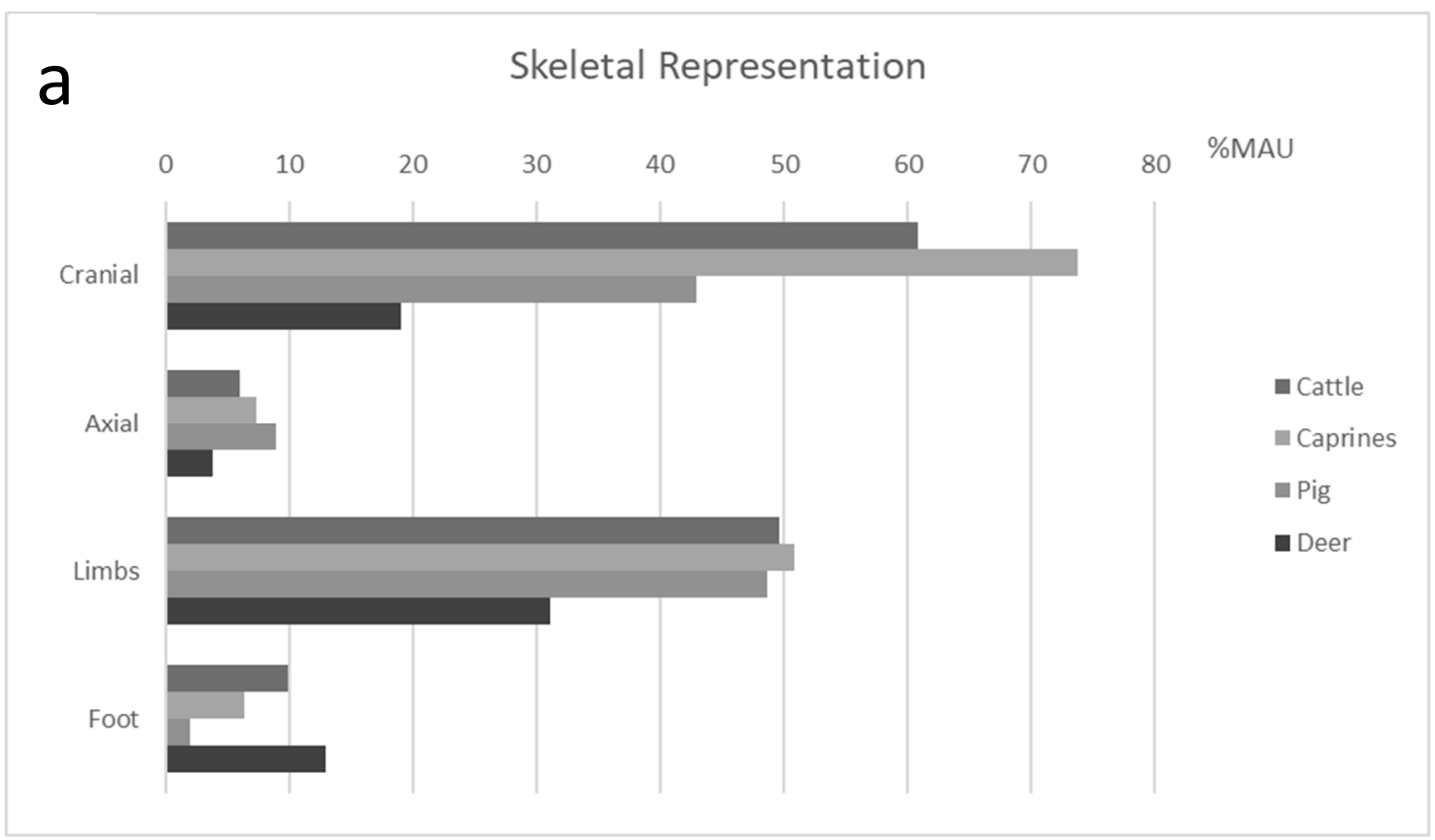

273

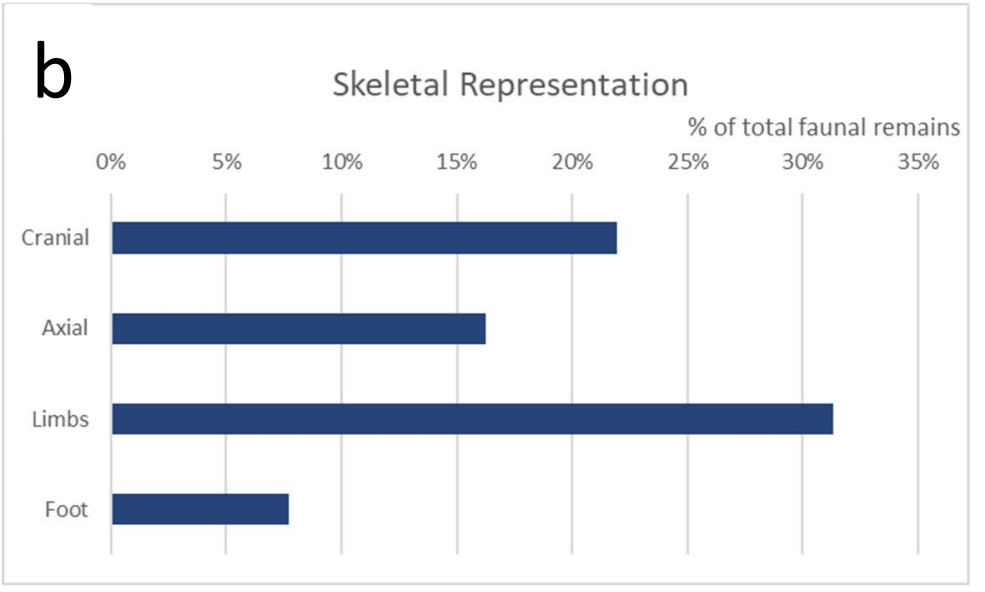

275 Fig. 6: a: Skeletal representation per main species in percentage of MAU (Minimal Animal Unit) of the faunal assemblage of La Motte I. b:

276 Skeletal representation of all species taken together as a percentage of total faunal remains of La Motte I.

277 The analysis of skeletal representation reveals no major differences between domestic and wild

278 species. The foot category for pigs is rare. The skeletal representation of deer shows that limb bones

279 outweigh those of the skull and the foot category is well represented in comparison to the axial

280 category. As deer are wild hunted animals, we can assume that the carcass would have been

281 processed differently to domestic species. Taponomic bias could play a major role in this particular

282 skeletal distribution, as small parts may have been moved away by the river current. But this

283 hypothesis is challenged by the presence of rabbit bones and rare sea bream jawbones. Underwater 
excavation conditions can also generate biases and although the diving excavators were experienced,

285 it was complicated to take samples for sieving under these conditions. This could impact the representativeness of very small fish remains, but this is not the case for mammalian remains.

287 Therefore, it is more likely that this particular skeletal representation is due to anthropogenic

288 selection, with limbs reflecting culinary waste and cranial remains being rejected after removing

289 edible parts (as evidenced by some anthropogenic marks at the junction of the jaws). The scarcity of 290 axial and appendicular parts of the skeleton could mean that inedible parts of the animal were

291 discarded elsewhere.

$292 \quad 4.4$ Mortality profiles

293 Mortality profiles were only calculated for teeth, taking into account the stage of wear and dental 294 eruption. 

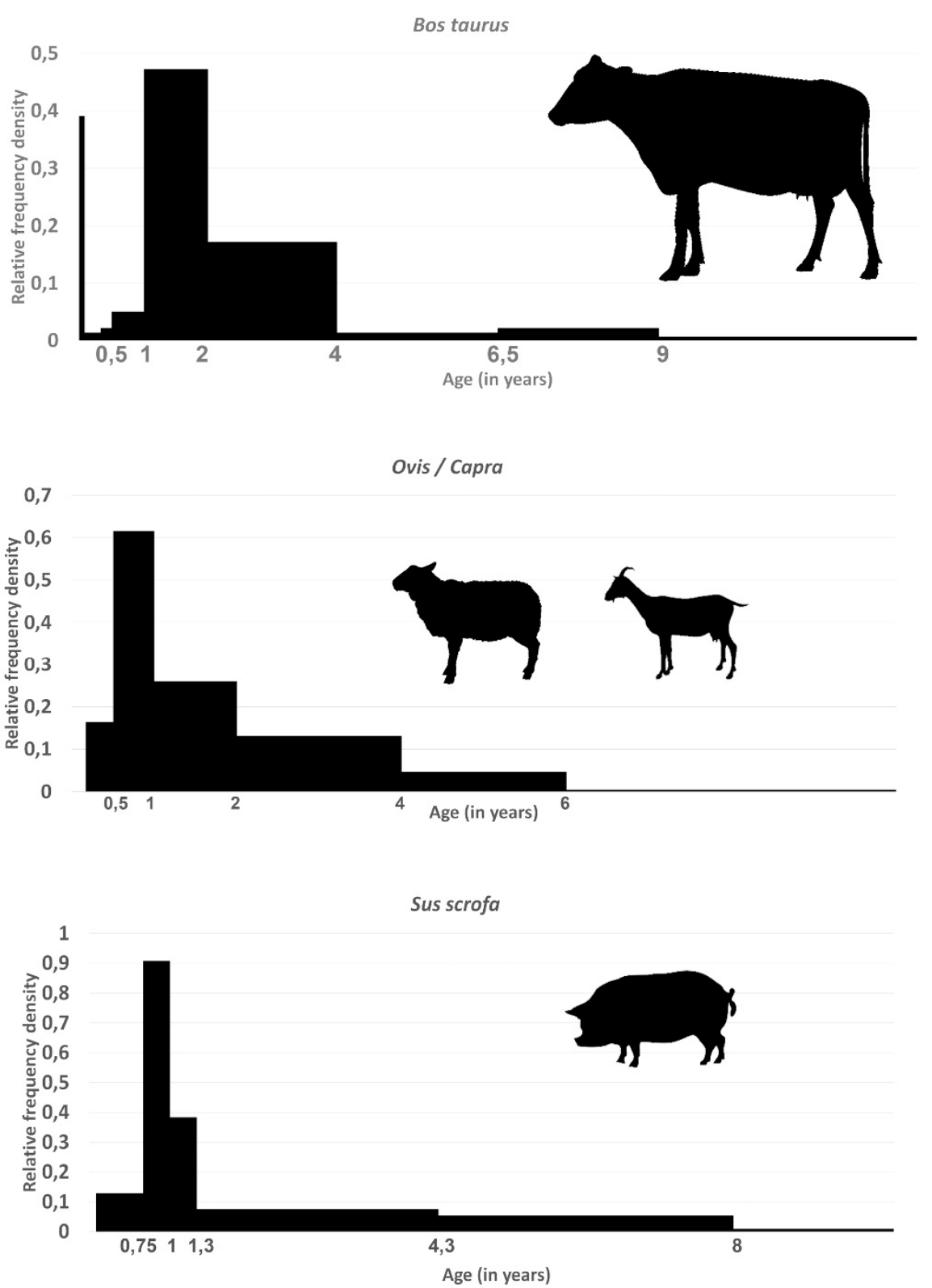

Fig. 7: Domestic triad culling profile, based on wear stages and dental eruption. Number of cattle teeth: upper=36, lower=56; caprine teeth: upper=74, lower=155; suids teeth: upper=19, lower=41.

\subsubsection{Cattle}

299 The combination of lower and upper teeth $(\mathrm{N}=92)$ was used to calculate mortality profiles. AtD

300 results reflect a strong slaughter peak between 1-2 years (Fig. 7) and subtle peaks at 0-1 months and

301 2-4 years. This could reflect multiple practices: killing calves for tender meat, slaughtering prime adults for maximum meat yields and slaughtering retired lactating females and old males for herd 
management (Gillis et al., 2016). In this case, we cannot confidently identify dairy farming (Greenfield, 2005; Greenfield and Arnold, 2015; Helmer et al., 2007; Payne, 1973).

\subsubsection{Caprines}

For sheep and goats, the culling profile peaks between 6 months and 1 year, followed by a slight peak at 1-2 years ( $\mathrm{N}=229$, Fig. 7). This depicts an emphasis on tender meat (Helmer and Vigne, 2004; Payne, 1973). However, traces of slaughtering of older adults are also visible in this histogram. Again, this implies that animals were culled post-lactation or for wool farming.

\subsubsection{Suids}

Young pigs ( $N=60)$ were slaughtered mainly between 10 and 12 months of age (Fig. 7). This may reflect a preference for tender, high-quality meat. Culling older pigs (aged 1 to 4 years) can be interpreted as a quest for maximum meat yields and the killing of pigs over 4 years of age can occur after fattening or at the end of reproductive functions.

The three mortality profiles correspond to a "tender meat" profile. The age limit for older cull animals ( 9 years for cattle, 6 years for caprines and 8 years for Suidae) may indicate their use for secondary production and herd birth-rate management, in order to always have a large number of young individuals available.

\subsection{Taphonomic alterations}

The underwater environment of the site caused specific polishing of the cortical surface of the bones. Almost all the remains are light brown to dark brown. The entire assemblage $(1,321$ faunal remains) was observed for taphonomic alterations. Most of the bones underwent superficial dissolution due to the fluvial context. Some of them present specific marks made by seaweed and small marine bivalves. Carnivores caused a number of changes in the bone surface as $20 \%$ of the total assemblage shows gnawing by carnivores. This indicates that culinary waste was accessible to commensal species and that landfill of the remains was slow. Burnt remains are easily distinguishable from natural 
staining, as burn marks are black or grey/white while natural staining colours bones soft brown to

328 dark brown. The number of burnt remains is very low.

\subsection{Anthropogenic marks}

330 Cutting marks were identified on $10 \%$ of the 1,321 faunal remains and $17 \%$ of NISP (Fig.8) on all

331 mammalian species: Bos taurus, Bos primigenius, Sus scrofa, Ovis aries, Capra hircus, Canis lupus

332 familiaris, Oryctolagus cuniculus, Equus caballus and Cervus elaphus.
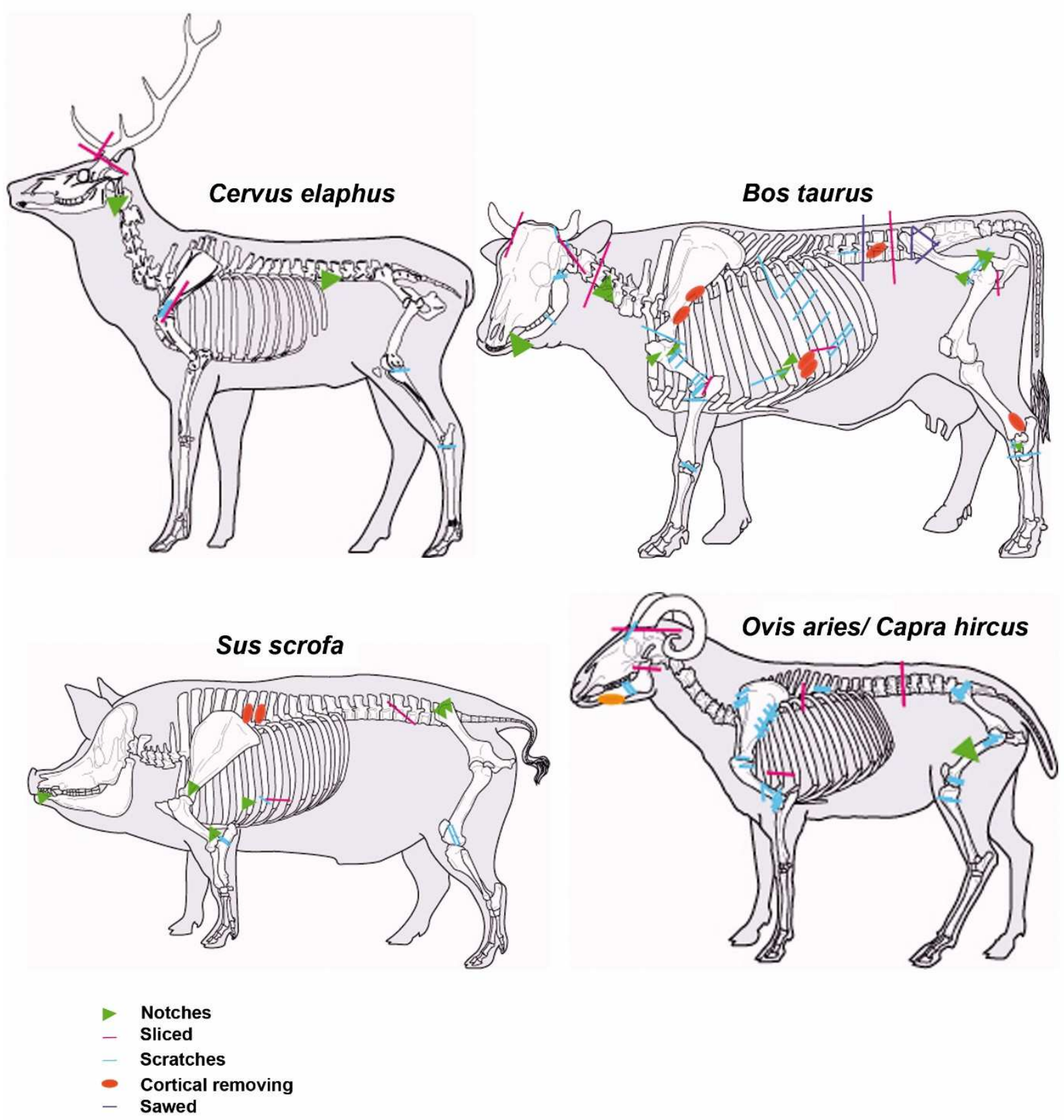
335 Five categories of anthropogenic cutting marks were observed on cortical bone surfaces. These highlight the stages of carcass processing such as disarticulation, removal of horns and feet, skinning and cutting meat, among others (Gardeisen, 1999). These observations demonstrate some slight differences between the consumed species. Indeed, butchery techniques vary with the size of the animal: for large mammals such as cattle and deer, large tools such as meat cleavers or saws are preferred, while knives are used for medium-sized mammals such as caprines or suids. Cut marks are mainly located on limbs (48\%), or on the diaphysis just below the joint surface, suggesting disarticulation and meat removal (Lyman 1987, 1994; Soulier and Costamagno 2017). The only common butchery technique to all four species is observed on lumbar vertebrae (slicing or notching), indicating the separation of the hindquarters. For large mammals (cattle and deer), marks on the cervical vertebrae indicate dissociation of the head. Scratches on carpals and tarsals show disarticulation of the feet and possibly skinning. The deer is the only animal with a longitudinal cut mark on the scapula, probably to remove the meat. Most of the time, cattle and caprines had their horns and antlers cut off, probably for artisanal purposes, although there is no real evidence of this. This can also be interpreted as a phase of skinning. The disarticulation of the femur-tibia connection is observed for all animals except cattle, but the latter are only represented by one entire femur. This reveals that the hind legs were generally separated into two parts for consumption. The heads of cattle show different treatment compared to other species. Analysis of the cut marks plausibly demonstrates the removal of the tongue, jaws and muzzle. Ruminants present similarities such as the removal of the ligament of the scapula and humerus, probably in order to isolate the joints. The cutting of ribs and the removal of meat from ribs and thoracic vertebrae are present on all three taxa. Thin crossed scratches situated along the caudal rim of a caprine scapula seem to indicate on-

357 site consumption. astragalus of Bos primigenius also shows cut marks and suggests that this animal was hunted. There 


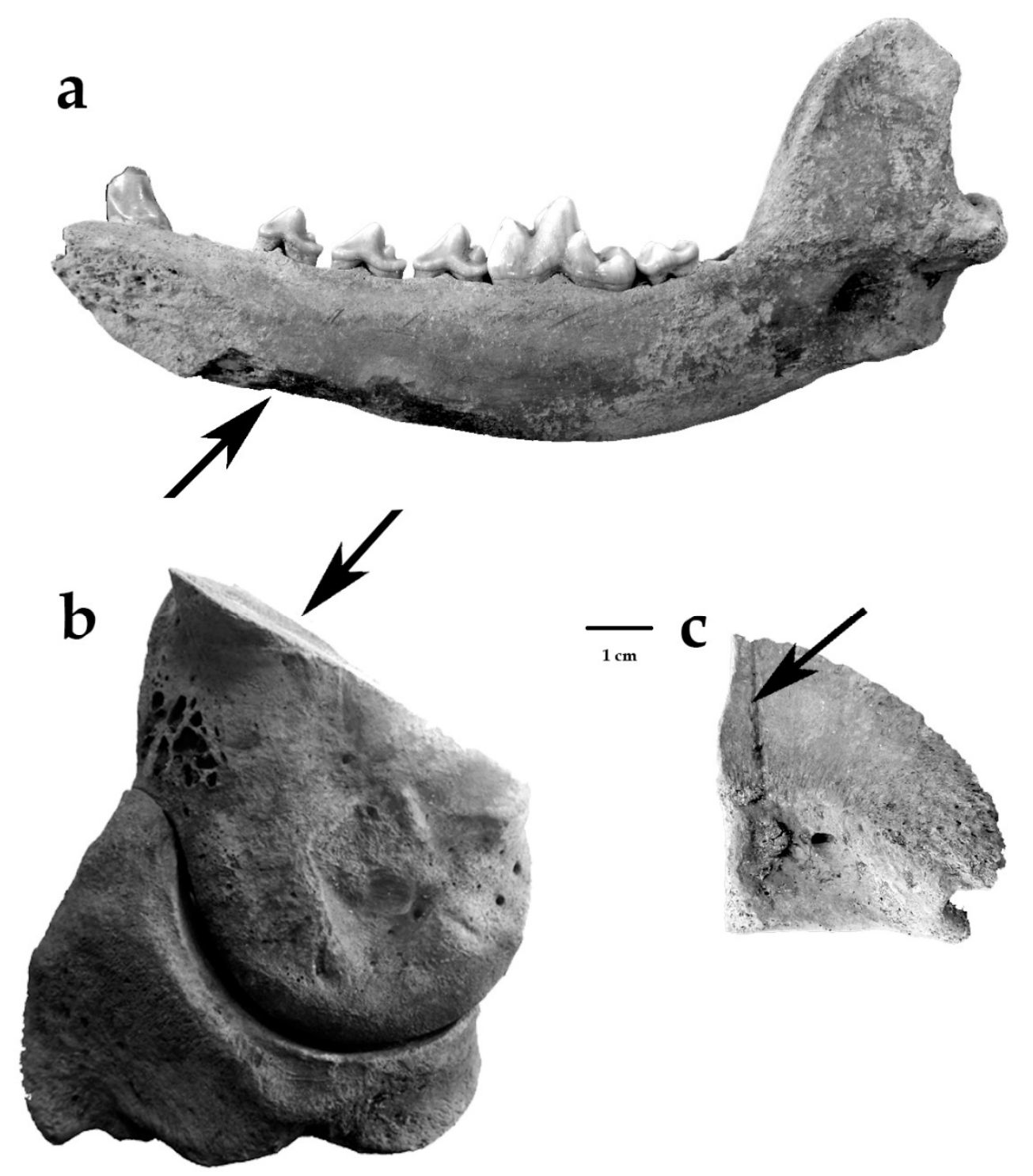

Fig. 9: Butchery marks (arrows) visible on bones from La Motte I. a: cortical ablation on canine mandibular base (Canis lupus familiaris), horse (Equus caballus) with medial cut mark (distal view).

\section{Discussion}

It is generally accepted that at the end of the Bronze Age, the notion of territorial concentration 
and Pion, 1992; Pautreau, 1992). However, the present zooarchaeological study implies that the lifestyle of the inhabitants on the Languedoc coast seemed quite similar to that of the elites. They ate tender meat and herd management focused on producing young animals, as at the elite site of Boulancourt (Seine-et-Marne, France). Indeed, the mass slaughter of young animals is not a longterm solution for herd management and shows that the inhabitants of La Motte had a comfortable way of life. This is also evidenced by the rich feminine bronze set recovered during the early excavations of the lagoon site, attesting to the presence of a local elite. La Motte I therefore seems to be a much more important site than previously thought, with a high standard of living and families probably belonging to a local elite.

Unfortunately, faunal data from Late Bronze Age breeding sites are lacking in France (especially in Languedoc), most often due to the scarcity of remains (less than 100 remains per site in general). This makes it difficult to interpret mortality profiles, for example. The results from La Motte I could be compared with those of lagoon sites around the Or Lagoon (Columeau, 1985) but no in-depth faunal analyses are available for the latter. Age at death categories only include three groups in Columeau's analysis: very young, young and adult individuals. According to his study, caprines and pigs predominate in the young category, and cattle in the adult category as a percentage of MNIs. However, these results should be considered with caution as there is no subadult class and no explanation of the methods used for ageing. For other rural sites in northern France, some compiled analyses (Auxiette, 1997) show an emphasis on pig farming, which is not the case here. But we cannot deduce with certainty whether this is due to cultural, environmental or social differences.

The second point is that, despite the presence of the lagoon at the edge of the settlement site, fish remains are rare on the site. This may be due to the lack of systematic sieving for very small fish bones but some medium-sized fish remains were recovered, such as sea bream. Agropastoral activities therefore seem to supply significant subsistence resources. Carpological and entomological analyses (Bouby et al., 2016) of the organic layers of the site backed up this general interpretation. 
They revealed numerous carbonized seeds and leaf remains, as well as plant residues interpreted as animal litter and two species of insects (Aglenus brunneus and Platytomus tibialis), linked to livestock stalls and the accumulation of old manure. Meanwhile, fishing is evidenced by a bronze hook adapted to fishing for large predators. This suggests that large fish remains should have been recovered, but they have only been found in small quantities at La Motte I. It can therefore be assumed that the population fished at sea and ate shellfish, but that this was not the main activity of the settlement. La Motte I was not a fishery.

As far as large animal hunting practices are concerned, they do not appear to have been vital for subsistence, but were perhaps linked to proving the value and strength of hunters. Although only three aurochs remains have been recovered on the site so far, the height of the hunted animal implies that this was a difficult mission. It can be also assumed that it was killed for security reasons, as the exceptional size of the animal would have represented a danger for the community living there. As regards small game hunting, the scarcity of rabbit remains does not allow us to draw a definite conclusion. Only one coxal shows signs of meat removal. There are also some bird remains, but no anthropogenic marks have been observed on bird bones. In addition, the presence of the cormorant, which is a species living in the aquatic environment, may be coincidental here. All the hunted species could potentially live near the settlement: deer could be present in the nearby riparian forest and rabbits in the surrounding salt marshes. It can therefore be assumed that hunting was opportunistic.

\section{Conclusion}

The results of this zooarchaeological analysis depict a faunal spectrum dominated by the domestic triad (cattle, pigs and caprines), with significant hunting activity (deer and lagomorphs). Butchery activities are attested by bone remains presenting anthropogenic cut marks. This is supported by the trend in culling profiles highlighting a preference for quality and tender meat consumption. This type 
of herd management requires a privileged social environment. Minor canine meat consumption is also noteworthy. Thus, although halieutic resources such as sea shells and fish were found on the site, it appears that the livelihood strategies of the Late Bronze Age population of La Motte I included animal husbandry and the consumption of a large amount of meat despite the proximity of the lagoon. The present faunal study shows a preference for the consumption of tender meat, while the presence of the female bronze set suggests that this lagoon settlement enjoyed priviledged status. This indicates that - at least in some cases - lagoon sites could be important and influential areas and not merely satellite sites of fortified hilltop settlements.

Acknowledgements: This research work is supported by a doctoral contract from Doctoral School 60 at Paul-Valéry Montpellier III University and the Labex Archimède "Future Investment" program ANR-11-LABX-0032-01. I wish to thank the reviewers for their constructive advice.

Declaration of interest: none

Appendices: Table A

References:

Arnal, J., Prades, H., 1980. Les ports lagunaires de la région de Montpellier. Bulletin du Musée d'Anthropologie préhistorique de Monaco. 24, 115-139.

Auxiette, G., 1997. La faune des établissements ruraux du Bronze final au Hallstatt final/La Tène ancienne dans la vallée de l'Aisne. Revue archéologique de Picardie. 3, 29-71. https://doi.org/10.3406/pica.1997.2250.

Bãlãsescu, A., Simonin, D., Vigne, J.-D., 2008. La faune du Bronze final Illb du site fortifié de Boulancourt « le Châtelet » (Seine-et-Marne). Bulletin de la Société Préhistorique Française. 105, 371-406. https://doi.org/10.3406/bspf.2008.13805.

Balasse, M.H., Ambrose, S., 2005. Distinguishing sheep and goats using dental morphology and stable carbon isotopes in C 4 grassland environments. Journal of Archaeological Science. 32, 691-702. https://doi.org/10.1016/j.jas.2004.11.013. 
Boessneck, J., 1969. Osteological differences between sheep (Ovis aries Linné) and goat (Capra hircus. Linné), in: Brothwell, D.-R., Higgs, E.-S. (Eds), Science in archaeology, A comprehensive survey of progress and research. Thames \& Hudson, London, 331-58. Bouby, L., 2014. L'agriculture dans le bassin du Rhône du Bronze final à l'Antiquité. Agrobiodiversité, économie, cultures, Toulouse.

Bouby, L., Ponel, P., Girard, V., Chia, T. C., Garnier, L., Tillier, M., Devillers, B., Lachenal, T., Tourrette, C., Gascó, J., 2016. Premiers résultats carpologiques et entomologiques sur le site subaquatique Bronze final de la Motte (Agde, Hérault) in: Dietsch-Sellami, M.F., Hallavant, C., Bouby, L., Pradat, B. (Dir.). Plantes, produits végétaux et ravageurs. Actes des $X^{e}$ Rencontres d'Archéobotanique, Les Eyzies-de-Tayac, 24-27 septembre 2014. Aquitania 36, Bordeaux, 65-87.

Brochier, J., 2013. The use and abuse of culling profiles in recent zooarchaeological studies: Some methodological comments on" frequency correction" and its consequences. Journal of Archaeological Science. 40, 1416-1420. 10.1016/j.jas.2012.09.028.

Brun, P., 1988. L'entité « Rhin-Suisse-France orientale »: nature et évolution, in: Brun, P., Mordant, C. (Eds.), Le groupe Rhin-Suisse-France orientale et la notion de civilisation des Champs d'Urnes. Actes du colloque international de Nemours, 1986. Mémoires du musée de Préhistoire d'île-de-France. 1, APRAIF, Nemours, 599-620.

Brun, P., Pion, P., 1992. L'organisation de l'espace dans la vallée de l'Aisne pendant l'Âge du bronze, in: Mordant, C., Richard, A. (Eds.), L'habitat et l'occupation du sol à l'Âge du bronze en Europe. Actes du colloque international de Lons-le-Saunier, 1990, CTHS, Paris, 117-127.

Callou, C., 1997. Diagnose différentielle des principaux éléments squelettiques du lapin (genre oryctolagus) et du lièvre (genre lepus) en Europe occidentale. Fiches d'ostéologie animale pour l'archéologie. Série B, mammifères, Centre de Recherche Archéologiques du CNRS, v.1, Juan-les-Pins.

Carozza, L., Burens, A., 2000. Les habitats du Bronze final de Portal Vielh à Vendres (Hérault). Bulletin de la Société préhistorique Française. 97, 4, 573-581.

Carozza, L., Marcigny, C., Talon, M., 2017. L'habitat et l'occupation des sols à l'âge du Bronze et au début du premier âge du Fer, CNRS Editions, Inrap, collection Recherches archéologiques 12, Paris. 
Columeau, P., 1985. La faune des gisements lagunaires (Bronze Final- ${ }^{\text {er }}$ Age du Fer), l'occupation des gisements lagunaires du Bronze final au ler Age du Fer. ARALO 13, Tome III, Caveirac, 123-130.

Columeau, P., 2002. Alimentation carnée en Gaule du Sud: (VIle s. av. J.-C.-XIVe s.). Publications de l'Université de Provence. 10.4000/books.pup.609.

Courtin, J., 1978. Recherches Archéologiques sous-marines. Gallia préhistoire. 21, 2, 735-746.

Daveau, I. (Dir.), 2007. Port-Ariane (Lattes, Hérault), Construction deltaïque et utilisation d'une zone humide lors des six derniers millénaires. Lattara 20.

Dedet, B., Py, M., Savay-Guerraz, H., 1985. L'Occupation des rivages de l'étang de Mauguio (Hérault) au Bronze Final et au premier Age du Fer, sondages et sauvetages programmés (1976-1979). ARALO 12. t.II, Caveirac.

Forest, V., 2000. Lots osseux fauniques archéologiques en Languedoc-Roussillon: Aperçu de leur composition du Néolithique final au bas Moyen-Age, in: Marandet, M.-C. (Ed.), l'Homme et l'animal dans les sociétés méditerranéennes. 4 ème journée d'études du Centre de Recherches Historiques sur les Sociétés Méditerranéennes, Presse universitaires de Perpignan, 15-26.

Forest, V., 2007. Etude archéozoologique des ossements de Port Ariane, in: Daveau, I., (Ed.), Port Ariane (Lattes, Hérault), Construction deltaïque et utilisation d'une zone humide lors des derniers six millénaires. Lattara, 20, Lattes, 281-309.

Gailledrat, E., Boisson, H., Poupet, P., 2007. Le Traversant à Mailhac (Aude): un établissement de plaine du Bronze final IIlb et du premier âge du Fer. Documents d'Archéologie Méridionale. ADAM éditions, 29/30, 19-74. http://journals.openedition.org/dam/1606.

Garcia, D., Vital, J., 2006. Dynamiques culturelles de l'âge du Bronze et de l'âge du fer dans le sud-est de la Gaule. Actes de la table ronde de Bologne, 28-29 mai 2005, Glux-enGlenne: Bibracte, Centre archéologique européen, 63-80.

Gardeisen, A., 1991. La Faune du Bronze final IIla, in: Dedet, B., Pène, J.M., La grotte I de Castelvielh à Sainte-Anastasie (Gard). Documents d'Archéologie Méridionale. 14, Le sanctuaire protohistorique de Roquepertuse. 89-123.

Gardeisen, A., 1997. Exploitation des prélèvements et fichiers de spécialités. Lattara 10, 260-270. 
Gardeisen, A., 1999. Découpe et consommation de viande au début du IV siècle avant notre ère. Quelques éléments de boucherie gauloise. Lattara 12. 569-587.

Gascó, J., 1998. Au terme de l'Age du bronze en Languedoc occidental (France), Le Bronze final IIla. Cypsela. 12, 147-160.

Gascó, J., Borja, G., Tourrette, C., Yung, F., Verdier, J.-L., Bouby, L., Devillers, B., Greck, S., Baisse, F., Barthelemy, C., Chabbert, J., Constant, D., Debrand, B., Dez, J., Iche, J.-C., Laurent, F., Puech, J.-P., Rouvet, P., Rolland, C., Sabastia, A., 2015. Une occupation lagunaire palafittique aux IXe-VIII ${ }^{\mathrm{e}}$ s. a.C.: La Motte (Agde) au fond du fleuve Hérault, in: Olmer, F., Roure, R.,(Eds.). Les Gaulois au fil de l'eau. Actes du XXXVII' colloque de I'AFEAF, Montpellier, 8-11 mai 2013, Bordeaux, Ausonius, 69-86.

Gillis, R., Chaix, L., Vigne, J.-D., 2011. An assessment of morphological criteria for discriminating sheep and goat mandibles on a large prehistoric archaeological assemblage (Kerma, Sudan). Journal of Archaeological Science. 38, 2324-2339. https://doi.org/10.1016/j.jas.2011.04.012.

Gillis, R., Carrère, I., Saña Seguí, M., Radi, G., Vigne, J-D., 2016. Neonatal Mortality, Young Calf Slaughter and Milk Production during the Early Neolithic of North Western Mediterranean. International Journal of Osteoarchaeology. 26, 303-313. https://doi.org/10.1002/oa.2422.

Greenfield, H.J., 2005. A reconsideration of the secondary products revolution in southeastern Europe: on the origins and use of domestic animals for milk, wool, and traction in the central Balkans, in: Mulville, J., Outram, A. The Zooarchaeology of Fats, Oils, Milk and Dairying. $9^{\text {th }}$ ICAZ Conference, Durham 2002, 14-31.

Greenfield, H.J., Arnold, E.R., 2015. 'Go(a)t milk?’ New perspectives on the zooarchaeological evidence for the earliest intensification of dairying in south eastern Europe. World Archaeology. http://dx.doi.org/10.1080/00438243.2015.1029076.

Grant, A., 1982. The Use of Tooth Wear as a Guide to the Age of Domestic Ungulates, in: Ageing and Sexing Animal Bones from Archaeological Sites. Oxford: B.A.R., BAR British series, 91-108.

Guy, M., 1950. La station du Roc de Conilhac. Revue d'études ligures. 16, 118-125.

Halstead, P., Collins, P., Isaakidou, V., 2002. Sorting the Sheep from the Goats: Morphological Distinctions between the Mandibles and Mandibular Teeth of Adult 
Ovis and Capra. Journal of Archaeological Science. 29, 545-553. https://doi.org/10.1006/jasc.2001.0777.

Helmer, D., 2000. Discrimination des genres Ovis et Capra à l'aide des prémolaires inférieures 3 et 4 et interprétation des âges d'abattage : l'exemple de Dikili Tash (Grèce). Anthropozoologica. 31, 29-38.

Helmer, D., Gourichon, L., Vila, E., 2007. The development of the exploitation of products from Capra and Ovis (meat, milk and fleece) from the PPNB to the Early Bronze in the northern Near East (8700 to 2000 BC cal.). Anthropozoologica. 42, 2, 41-69.

Helmer, D., Vigne, J.-D., 2004. La gestion des cheptels de caprinés au Néolithique dans le Midi de la France, in: Bodu, P., Constantin, C., (Eds), Approches Fonctionnelles en Préhistoire. Actes du XXVème Congrès Préhistorique de France, Nanterre, 2000. Mémoires de la Société Préhistorique Française. Numéro spécial, 397-407.

Helmer, D., Monchot, H., 2006. Un site Mésolithique de chasse à l'aurochs (La Montagne, Sénas, Bouches-du-Rhône). Anthropozoologica. 41, 2, 215-228.

Janin, T., 2000. Mailhac et le premier Âge du fer en Europe occidentale, Hommage à Odette et Jean Taffanel. Actes du colloque international de Carcassonne, 17-20 septembre 1997. Monographies d'Archéologie Méditerranéenne. 7, Lattes, 2000, 185-194.

Kiesewalter, L., 1888. Skelettmessungen an Pferden als Beitrag zur theoretischen Grundlage der Beurteilungslehre des Pferdes. Diss. Leipzig.

Kyselý, R., 2008. Aurochs and potential crossbreeding with domestic cattle in Central Europe in the Eneolithic period. A metric analysis of bones from the archaeological site of Kutná Hora - Denemark (Czech Republic). Anthropozoologica. 43, 7-37.

Lachenal, T., 2014. Chronologie de l'âge du Bronze en Provence, in: Sénépart, I., Leandri, F., Cauliez, J., Perrin, T., Thirault, E. (Eds.), 2014. Chronologie de la Préhistoire récente dans le sud de la France, acquis 1992-2012, actualités de la recherche. Actes des $10^{\mathrm{e}}$ Rencontres Méridionales de Préhistoire Récente, Porticcio,18-20 octobre 2012. Archives d'Ecologie Préhistorique, Toulouse, 197-220.

Lachenal, T., Gascó, J., Devillers, B., Greck, S., Lespes, C., 2017. La Motte (Agde, Hérault), Habitat immergé du Bronze final. Rapport de fouille programmée subaquatique, DRAC, SRA Occitanie. 
Legge, A.-J., 1992. Excavations at Grimes Graves Norfolk 1972-1976, Fascicule 4: Animals, Environment and the Bronze Age Economy. British Museum Press, London.

Lemoine, X., Zeder, M.A., Bishop, K.J., Rufolo, S.J., 2014. A new system for computing dentition-based age profiles in Sus scrofa. Journal of Archaeological Science. 47, 179193. https://doi.org/10.1016/j.jas.2014.04.002.

Leroy, F., Bouby, L., Guibal, F., 2003. Les gisements protohistoriques de l'étang de Thau (Hérault), in: Gascó, J., Gutherz, X., de Labriffe, P.-A. (Dir.), Temps et espaces culturels du Gème au 2ème millénaire en France du Sud. Actes des 4ème Rencontres Méridionales de Préhistoire Récente, Nîmes 2000. Monographies d’Archéologie Méditerranéenne. 15, Lattes, 369-376.

Louis, M., Taffanel, O., Taffanel, J., 1955. Le premier Âge du Fer languedocien, Les habitats. I, Bordighera-Montpellier.

Lyman, R.L., 1987. Archaeofaunas and butchery studies: a taphonomic perspective. Adv. Archaeol. Method Theory 10, 249-337.

Lyman, R.L., 1994. Vertebrate Taphonomy. Cambridge University Press, Cambridge.

Lyman, R.L., 2008. Quantitative Paleozoology. Cambridge University Press, Cambridge.

Matolcsi, J., 1970. Historische Erforschung der Köpergrösse des aufgrund ungaririschen Knöchen material. Ztschr. F. Tierzücht und Züchtungsbiol, 87, Hamburg, 89-137.

Moyat, P., Dumont, A., Mariotti, J.-F., Janin, T., Greck, S., Bouby, L., Ponel, P., Verdin, P., Verger, S., 2010. Découverte d'un habitat et d'un dépôt métallique non funéraire du VIII s. av. J.-C. dans le lit de l'Hérault à Agde, sur le site de La Motte. Jahrbuch des Römisch-Germanischen Zentralmuseums Mainz. 54, 53-84.

Pautreau, J.P., 1992. Cimetières villageois, villages, nécropoles sanctuaires de la fin du Bronze au Premier Âge du fer dans le Centre-Ouest de la France (1000-500 av. J.-C.), in: Mordant, C., Richard, A. (Eds.), L'habitat et l'occupation du sol à l'Âge du bronze en Europe. Actes du colloque international de Lons-le-Saunier, 16-19 mai 1990, CTHS, Paris, 293-302.

Payne, S., 1973. Kill-off Patterns in Sheep and Goats: The Mandibles from Asvan Kale. Anatolian Studies. 303.

Payne, S., 1985. Morphological distinctions between the mandibular teeth of young sheep, Ovis, and goats, Capra. Journal of Archaeological Science. 12, 2, 139-147. 
Payne, S., 1987. Reference codes for wear states in the mandibular cheek teeth of sheep and goats. Journal of Archaeological Science. 14, 609-614. https://doi.org/10.1016/0305-4403(87)90079-3.

Poplin, F., 1976. A propos du Nombre de Restes et du Nombre d'individus dans les échantillons d'ossements. Cahiers du Centre de Recherches Préhistoriques, 5, 61-74.

Poulain, T., 2002. Les restes d'animaux, in: Dedet, B., Rouquette, D., L'habitat du Bronze final des Courtinals à Mourèze (Hérault), Documents d'archéologie méridionale. 25, 33-63. http://dam.revues.org/158.

Prades, H., 1974. Les terramares melgoriens. Mauguio.

Py, M., 1990. Culture, économie et société protohistoriques dans la région nîmoise. Ecole française de Rome, 131, 2 vol., Rome.

Py, M., 1997. SYSLAT 3.1. Système d'Information Archéologique. Manuel de référence. Lattara 10.

Py, M., 2012. Les Gaulois du Midi, de la fin de l'Âge du Bronze à la conquête romaine. Collection Les Hespérides, Errance, Paris.

Reitz, E.J., Wing, E.S., 1999. Zooarchaeology. Cambridge University Press.

Salvagno, L., Albarella, U., 2017. A morphometric system to distinguish sheep and goat postcranial bones, PLoS ONE. https://doi.org/10.1371/journal.pone.0178543.

Soulier, M.-C., Costamagno, S., 2017. Let the cutmarks speak! Experimental butchery to reconstruct carcass processing. Journal of Archaeological Science: Reports. v.11, 782802.

Teichert, J.R., 1975. Osteometrische Untersuchungen zur Berechnung der Widerristöhe bei Schafen, in: Clason, A.T. (Ed.), Archeozoological Studies. Amsterdam, 51-69.

Verger, S., Dumont, A., Moyat, P., Mille, B., 2007. Le dépôt de bronzes du site fluvial de La Motte à Agde (Hérault). Jahrbuch des Römisch-Germanischen Zentralmuseums Mainz. 1, 85-171.

Von den Driesch, A., 1976. A guide to the measurement of animal bones from archaeological sites. Bulletin of the Peabody Museum of Archaeology and Ethnology. Harvard University, Cambridge, 1.

Wright, E., 2013. The history of the European aurochs (Bos primigenius) from the Middle Pleistocene to its extinction: an archaeological investigation of its evolution, 
morphological variability and response to human exploitation. PhD. University of Sheffield.

Wright, L., Viner-Daniels, S., 2015. Geographical variation in the size and shape of the European aurochs (Bos primigenius). Journal of Archaeological Science. 54. https://doi.org/10.1016/j.jas.2014.11.021.

Zeder, M., A. Lapham, H., 2010. Assessing the reliability of criteria used to identify postcranial bones in sheep, Ovis, and goats, Capra. Journal of Archaeological Science. 37, 2887-2905. https://doi.org/10.1016/j.jas.2010.06.032.

Zeder, M., Pilaar Birch, S., 2010. Assessing the reliability of criteria used to identify mandibles and mandibular teeth in sheep, Ovis, and goats, Capra. Journal of Archaeological Science. 37. https://doi.org/10.1016/j.jas.2009.10.002.

Zeder, M. A., Lemoine, X., Payne, S., 2015. A New System for Computing Long-Bone Fusion Age Profiles in Sus Scrofa. Journal of Archaeological Science. 55, 135-50. 